\title{
Death Certification Indicator
}

National Cancer Institute

\section{Source}

National Cancer Institute. Death Certification Indicator. NCI Thesaurus. Code C135385.

An indication as to whether a death certificate was obtained. 